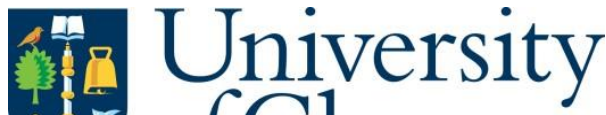 of Glasgow
}

Gao, H., Shen, Z., Li, Y., Mao, X. and Shi, Y. (2020) Institutional investors, real earnings management and cost of equity: Evidence from listed high-tech firms in China. Emerging Markets Finance and Trade, 56(14), pp. 3490-3506. (doi: 10.1080/1540496x.2019.1650348)

The material cannot be used for any other purpose without further permission of the publisher and is for private use only.

There may be differences between this version and the published version. You are advised to consult the publisher's version if you wish to cite from it.

\section{http://eprints.gla.ac.uk/194034/}

Deposited on 12 September 2019

Enlighten - Research publications by members of the University of Glasgow http://eprints.gla.ac.uk 


\title{
Institutional Investors, Real Earnings Management and Cost of Equity: Evidence from Listed High-tech Firms in China
}

\begin{abstract}
This paper investigates the association between real earnings management and the cost of equity from the perspective of the heterogeneity of institutional investors. Based on a sample of publicly listed high-tech firms in China from 2008 to 2017, our empirical results suggest that there is a significant negative correlation between earnings management and the cost of equity capital. This finding is contrary to Kim and Sohn's (2013) conclusion, indicating that, in China, real earnings management cannot be effectively identified by external investors, and the company could easily obtain financing from the capital market and reduce its cost of equity due to its masked excellent performance by manipulating the real earnings management. Furthermore, we find that compared with transient institutional investors, stable institutional investors with the intention of holding the stock for the long-term can effectively reduce the cost of equity. Our results also show that real earnings management under the supervision of stable institutional investors could be more easily identified by shareholders and stable institutional investors could diminish the impact of earnings management on the cost of equity.
\end{abstract}

JEL: G31 G32

Key words: Institutional Investors; Earnings Management; Cost of Equity; High-tech enterprises 


\section{Introduction}

Earnings management is defined as judgement exercised by managers in financial reporting to adjust financial reports. This behavior will mislead stakeholders' judgement of the company's performance and will also affect potential investors' investment judgment (Healy and Wahlen, 1999) and finally influence companies' cost of equity. Previous studies indicate that managers' concerns about current performance motivate them to engage in manipulating current period earnings at the expense of future period earnings (Stein, 1989; Fudenburg and Tirole, 1995; Pauwels et al., 2004; Graham et al., 2005; Rodriguez-Perez and Van Hemmen, 2010). As external investors and analysts typically form their expectations based on future earnings, in most cases, a variety of contractual obligations (e.g., earnings-based bonus contracts and debt covenants) are linked to current period reported earnings. This often leads to managerial myopia in which the managers are overly concerned with boosting current performance, such as stock prices. Thus managers have incentives to inflate current earnings by borrowing future earnings for use in the current period so that the operation performance could be affected by the upward trend and the managers with stock-based compensation could benefit from their own soaring shares. Therefore, external investors are often misled by current earnings profits, overconfident in masked excellent performance, and mistakenly regard the 
companies as 'white horse stocks' or value investments, thus reducing the expected return on investment. Because of its masked excellent performance by manipulating the real earnings management, the company can easily obtain financing from the capital market and reduce its cost of equity. This finding leads to our first prediction that earnings management has a negative association with the cost of capital.

Due to the imperfect regulations of the Chinese capital market system and the low-level protection for individual investors, this type of earnings management behavior is usually found in Chinese listed companies to avoid reporting losses (Wang, 2005). In light of the adverse effects of earnings management, a large number of scholars have studied the relationship between institutional investors and earnings management. Chung et al. (2002), Cheng (2006), Gao and Zhang (2008) find that the proportion of institutional investors' shareholding is negatively correlated with the degree of earnings management. This finding indicates that institutional investors could effectively inhibit the management of earnings management behavior, but these studies are limited by a lack of empirical samples. Additionally, their conclusions are limited because institutional investors were found mainly in the initial stage during that period in China. With the prosperity of the Chinese capital market, the development of institutional investors began to diversify. Based on the endogenous perspective, Mei and Zhang (2016) find that compared with other institutional investors, securities investment funds have a significant inhibitory effect on earnings management behavior of their shareholding companies, and they are the dominant force in institutional investors to participate in corporate governance. Nevertheless, in the background of the imperfect governance structure of listed companies in China, whether institutional investors undertake short-term speculation to obtain capital gains 
or make long-term investment to support the development of enterprises to obtain dividends has an increasingly overwhelming impact on the cost of equity on the capital market.

In brief, this paper investigates the hitherto unexplored questions of whether real earnings management(hereafter REM) activities influence a firm's cost of equity(hereafter $\mathrm{CoE}$ ) based on the high-tech companies listed in China, all else being equal. We are motivated to test the relationship between REM and CoE, because the cost of equity is a key factor reflecting the expected return for the outside investors, and it even determines all social resource allocation decisions. We find a contrary conclusion to Kim and Sohn's (2013) that REM is negatively associated with the cost of capital in China because REM is more difficult for investors to understand, and is normally less subject to monitoring and scrutiny by auditors, regulators and other outside stakeholders. This finding implies that in China, these REM activities could have direct influences on cash flow from business activities, thus the other external stakeholders and potential investors could be deceptive and decide to invest based on the masked financial report, which leads to a decrease in the investors' expected return. Second, from the perspective of institutional investors, we examine whether a firm's cost of equity will be influenced by institutional investor heterogeneity by comparing the impact of real earnings management behavior on the cost of equity capital for the two different institutional investor types at the same time. We find that real earnings management under the supervision of the stable institutional investors could be more easily identified by shareholders. Stable institutional investors could diminish the earnings management's impact on the cost of equity.

The contributions of this paper relative to previous research are listed below. First, the previous literature on institutional investor measurement is based on 
different types of institutional investors, such as securities funds, QFII, insurance companies and social security funds in China. This paper examines the impact of the heterogeneity of institutional investors by dividing investors into stable and transactional institutional investors, also paying attention to the response of earnings management on the cost of equity under the stable institutional investors group and transient institutional investors group respectively, demonstrating the importance of stable institution investors' role from another point of view. Second, most Chinese scholars tend to choose the absolute value of discretionary accruals (DA) to measure earnings management, but few studies have explored the relationship between real earnings management (REM) and the cost of equity capital. Based on the panel data model, this paper studies the association between real earnings management and the cost of equity in high-tech enterprises from the perspective of institutional investors and we find a contrary conclusion to that of Kim and Sohn's (2013). In addition, the samples in this paper based on high-technology enterprises have special significance for the pratical value of financing strategy selection and the selection of institutional investors for high-tech enterprises in the ten key high-tech manufacturing industries for the Made in China 2025 initiative

The remainder of the paper is organized as follows. Section 2 presents a brief review of the related literature and hypotheses. Section 3 provides details about the research design and sample selection procedure and develops our model. Section 4 presents our empirical findings. Section 5 contains the conclusion.

\section{Literature Review}

\subsection{Real Earnings Management}

In the literature, many studies (Francoeur et al.,2012; Datta et al., 2013; Chiu, et 
al.,2013; Kangarluei et al., 2011; Essid, 2012; Caton et al.,2011; He et al., 2011 Degeorge et al., 2013; Hansen, 2010; Liu et al., 2014; Sun et al., 2014) related to earnings management focus only on identifying related factors that can significantly affect earnings management. However, these factors have not been used directly to forecast the level of earnings management in advance (Tsai \& Chiou, 2009).

Previous research has also examined earnings management by considering the decomposition of total accruals into their abnormal and discretionary components (Louis, 2004; Matsumoto, 2002; Roychowdhury, 2006; Jones, 1991; Dechow, et al.,1995; Liu et al.,2014; Patro and Pattanayak, 2014; Greiner, 2015). The conventional earnings management (i.e., linear accrual) models assume that the slope coefficients are constant within the sample, which means that observations in the sample have a uniform accrual-generating process (Bartov et al., 2000). If an accrual model estimates the coefficients within the same industry, it assumes that firms in the same industry have similar accrual-generating processes ( $\mathrm{Wu}, 2014)$. However, the uniform accrual-generating process assumption may not be proper for firms with extreme performance within the industry, leading to biased discretionary accrual estimates ( $\mathrm{Wu}, 2014)$.

To help investors in the stock market, it is necessary to develop a model that can predict the level of earnings management. Methods for predicting earnings management have been extensively researched. Classical statistical techniques influence the formation of these models, such as neural networks (Tsai \& Chiou,2009; Hoglund, 2012; Pourhasan \& Mansour,2014); decision trees (Tsai \& Chiou,2009); and Benford's Law (Lin \& Wu, 2014).

Current period reported earnings can be managed in two different ways. First, managers can manipulate reported earnings through discretionary accrual choices that 
are allowed under Generally Accepted Accounting Principles (GAAP). This within-GAAP discretionary accruals earnings management (hereafter DA) typically occurs at the end of an accounting period, after the completion of the most real operating activities. However, discretionary accruals earnings management (DA) has no direct effect on cash flows because it only influences the amount of accounting accruals directly. Second, managers can also manipulate reported earnings by distorting real activities. Specifically, they can alter the timing and scale of real activities such as production, sales, investments, and financing activities throughout the accounting period to meet a specific earnings target. For example, reported earnings can be temporarily boosted by accelerating the timing of production and sales schedules, by cutting discretionary expenditures, and by deferring the timing of their occurrences. According to Roychowdhury (2006), these real operation management activities that deviate from normal business practices with the primary objective of manipulating current period earnings are referred to as real earnings management (hereafter REM). Unlike DA, REM has direct consequences on current and future cash flows (as well as accounting accruals), which is more difficult for average investors to understand and normally less subject to monitoring and scrutiny by boards, auditors, regulators, and other outside stakeholders. This behavior may misguide investors regarding the required rate of return on investment projects, which reflects the cost of equity in the capital market, or worse, a mismatch of social resources.

\subsection{Relationship between Real Earnings Management (REM) and the Cost of Equity}

Kim and Sohn (2013) first predict that the cost of capital is positively associated with the extent of REM activities aimed at earnings manipulation, arguing that REM activities increase the cost of equity for two major reasons. First, REM introduces 
noise into reported earnings because noise affects accruals in addition to distorting cash flow through real operations-manipulating activities. Second, REM is typically seldom subject to external monitoring or scrutiny and is difficult to detect using internal monitors such as a board or audit committee. As a result, REM might not be curtailed by a good governance mechanism (Jaggi et al., 2009), thereby rendering external investors' evaluation of firm performance more difficult. Thus, managers can misappropriate more cash if their firms' true performance is masked by REM. This managerial opportunism causes outside investors to assess the expected level of future cash flows to be lower for REM-intensive firms, all else being equal.

However, the structure of investors in the Chinese capital market is defective; more than half of investors are individual investors who are more likely to be deceived by masked current performance and make blind investments. Additionally, institutional investors do not make in-depth research and earnings forecasts, and the herding effect is prominent. Kangmei Pharmaceutical Co, a listed high-tech pharmaceutical company in China, committed the financial crime of fabricating more than 29.9 billion bank deposits in its bank accounts from fiscal year 2016 to 2018, and external auditing institutions did not audit cash management problems during the previous three years, directly leading to serious losses in financial performance in the 2018 annual report. The annual reports for three consecutive years show that there were many well-known investment institutions among their shareholders. Although it is a type of fraud that makes the performance grow steadily, rather than earnings management implemented on cash flow, it proves that in China, it is difficult for external investors to evaluate companies' real performance through their financial reports. External investors are often misled by current earnings profits, overconfident in masked excellent performance, and mistakenly regard the company as 'white horse 
stocks', thus reducing the expected return on investment. Because of its masked excellent performance, a company can easily obtain financing from the capital market and reduce its cost of equity. This finding leads to our prediction that REM has a negative association with the cost of capital, as follows:

H1: Earnings management through REM activity manipulation is significantly negatively related to $\mathrm{CoE}$.

\subsection{Institutional Investors}

Institutional investors refer to financial institutions that maximize the benefits of capital management with more advantages in terms of professionals, scale, the ability to collect information, and more motivation to suppress corporate earnings management compared with individual investors. (Almazan et al., 2005; Chung and Zhang, 2011). As financial institutions and market mechanisms in the Chinese stock market is still immature, with insider trading, speculative investment behavior, and information asymmetry problems (Ding, Kim, and Zhang 2018), these institutional investors tend to release effective signals through buying and selling stocks, publishing research reports and investing ideas, which will attract the attention of individual shareholders and potential investors and ultimately affect the value of shareholding companies (Shi and Tong, 2009). However, most of the existing studies test the impact of institutional investors on earnings management based on the institutional investors' shareholding ratio, while the index of institutional investors' shareholding ratio cannot fully indicate the impact of institutional investors' stock ownership on the cost of equity capital through earnings management, since the index neglects the other factors beyond the dimension of the level of ownership. (Li et al, 2014). 
The study on the role of institutional investors in corporate governance has bloomed over the past twenty years. Research has shown that the role of institutional investors depends on the period of investment by institutional investors (Bushee, 2001; Gaspar et al., 2005). Bushee (1998) classifies institutional investors into three categories: (1) transient institutional investors who hold diversified portfolios with high turnover rates; (2) dedicated institutional investors who hold concentrated portfolios with low turnover; and (3) quasi-indexers who hold diversified portfolios with low turnover. Bushee (2001) finds that only transient -- but not long-term -institutional investors exhibit a preference for near-term earnings. These findings support the concerns that many managers have about the adverse effects of an ownership base dominated by short-term-focused (transient) institutional investors. Liu and Xu (2012) find that short-term institutional investors' transaction changes lead to the intensification of market volatility, and that long-term stable institutional investors play a certain role in stabilizing the market. The empirical result is consistent with our paper's opinion that institutional investors' choice between supervision and a short-term trading strategy is mainly determined by the stability of institutional investors.

2.4 Relationship among Institutional Investors, Earnings Management, and the Cost of Equity

Ping-Sheng Koh (2007) tests the relationship between institutional investors and the company's arbitrary earnings management by manipulating the accrued profit and finds that the stable institutional investors will restrict the management of earnings, while the number of speculative investors in the trading institutions does not have a systematic connection with excessive earnings management. Instead, they are more likely to earn a trading interest margin through frequent transactions. Shi and Tong 
(2009) find that the higher the proportion of institutional investors is, the higher the value of the enterprise is, and in the later period of the reform, the impact of institutional investors on the value of the enterprise has been significantly increased. Niu (2013) finds that institutional investors make less earnings by controlling ownership than other types of investors, so they pay more attention to the value of the enterprise. As a result of attempting to avoid weak performance, managers may have a greater incentive to exaggerate their earnings, show higher growth rates, increase stock prices and make investors more favourable to the business, leading to reducing the cost of equity. Therefore, we predict that institutional investors could exert the role of external governance to reduce the $\mathrm{CoE}$ and that stable institutional investors are more likely to diminish REM's impact on the CoE than transient investors. Therefore, the following hypothesis is proposed:

H2: Institutional investors are significantly negatively related to CoE, and stable institutional investors are more likely than transient investors to diminish the REM's impact on the CoE.

\section{Methodology}

Devesh Verma, Anant Mishra and Kingshuk K. Sinha (2010) take American high-tech enterprises as examples to illustrate that high-tech enterprises manipulate their accounting information by manipulating the real earnings management of $R \& D$ to achieve their performance goals. Daniel Olausson and Christian Berggren (2010) find that the uncertainty of management and the risk of development on innovation products motivate high-tech enterprises to use certain earnings management techniques to achieve their performance goals, and to exert certain impact on accounting information users. These unique characteristics of high-tech enterprises make them new targets for investors and creditors. Further, the problem of resource 
allocation between traditional industries and high-tech industry has become particularly prominent since China proposed an innovation-driven development strategy to encourage high-tech enterprises. China has promulgated the recognition criteria of "Measures for the Identification and Management of High-tech Enterprises" (No. 32 Document published by Chinese National Science and Technology Focus [2016] $)^{1}$, which can help high-tech companies obtain income tax relief; that is, the tax for high-tech enterprises is levied at $15 \%$ compared with the normal $25 \%$ income tax in China. The government offers those special tax incentives to high-tech enterprises to promote the comprehensive and healthy development of high-tech industries. This also provides a tax incentive that managers are more likely to implement earnings management to meet the benchmark and to obtain tax relief in China (note 1 referred above) from another perspective.

Therefore, we believe that it is necessary to conduct a unique study with this sample. In this paper, we finally find more than one thousand high-tech enterprises in accordance with No. 32 Document published by the Chinese National Science and Technology Focus in 2016 and we select 2008-2017 financial data for relevant collation. The data are collected from all companies publicly traded on China's Shanghai and Shenzhen Stock Exchange from the CSMAR database, Wind database and related annual reports. In this article, the samples collected from the 2008-2017 annual financial reports of high-technology enterprises exclude companies with the

${ }^{1}$ One of the Standards of Measure for the Identification and Management of High-tech Enterprises is that the proportion of total research and development expenditure divided by total sales income over the past three years must meet the following requirements:

1. If sales revenue is less than 50 million yuan in recent years, the proportion is not less than $5 \%$.

2. If sales revenue is from 50 million yuan to 200 million yuan in recent years, the proportion is not less than $4 \%$.

3. If sales revenue is more than 200 million yuan in recent years, the proportion is not less than $3 \%$.

Among them, the total R\&D expenditure incurred by enterprises in China accounts for no less than $60 \%$ of the total R\&D expenditure. 
absence of annual reports and ST companies to render the results more academic and objective. After the above screening, 7453 records were obtained.

\subsection{Cost of Equity}

The cost of equity financing refers to the minimum risk-adjusted rate of return that the company must earn to meet the requirements of shareholders or investors. We use the capital asset pricing model (CAPM) to estimate the cost of capital. The equilibrium yield of the risk asset is a function of the covariance (beta coefficient) of the market combination rate of return. The yield of the asset is equal to the risk-free interest rate plus the risk premium determined by the systematic risk. The formula of the asset pricing model is as follows:

$$
R_{s}=R_{f}+\beta\left(R_{m}-R_{f}\right)
$$

Based on the work of Jiang $(2006,2008)$ and other studies, this article uses CAPM to calculate the company's equity financing costs where $R_{f}$, the risk-free rate of return, is the average interest rate of the longest term treasury bonds traded on the Shanghai stock exchange and $\beta$ is the systematic risks for companies; additionally, the market annual yield is the total monthly average return (total market value weighted average method) considering cash dividends reinvestment multiplied by 12 .

\subsection{Real Earnings Management}

Roychowdhury (2006) developed empirical models for estimating the typical levels of real business activities, as reflected in the cash flow from operations, production costs, and discretionary expenditures. We use equation 2 to estimate the absolute value of $\varepsilon_{i t}$ to measure the abnormal level. 


$$
\frac{C F O_{i t}}{T A_{i t-1}}=\beta_{0} \frac{1}{T A_{i t-1}}+\beta_{1} \frac{S A L E S_{i t}}{T A_{i t-1}}+\beta_{0} \frac{\Delta S A L E S_{i t}}{T A_{i t-1}}+\varepsilon_{i t}
$$

where $C F O_{i t}$ is the cash flow from operations of company $i$ for year $t ; T A_{i t-1}$ is the assets of company $i$ for year $t-1 ; S A L E S_{i t}$ is the sales for year $t$; and $\triangle S A L E S_{i t}$ is the change in sales of company $i$ for year $t$;

In table 1, according to the equation of Roychowdhury's model, we multiply the two sides of the equation by the assets and perform the regression to obtain the coefficient and the residual. We take the absolute value of the residual division asset as the measure of real earnings management.

Table 1

Regressions of real earnings management based on Roychowdhury (2006)

\begin{tabular}{lll}
\hline Variables & Coef. & $\mathrm{p}>|\mathrm{t}|$ \\
\hline SALE & $0.0099284 * * *$ & 0.000 \\
$\triangle$ SALES & $0.1089522^{* * *}$ & 0.000 \\
Intercept & $1.21 \mathrm{E}+08 * * *$ & 0.000 \\
Adjusted $\mathrm{R}^{2}$ & 0.930 & \\
$\mathrm{~F}$ & $383.02 * * *$ & 0.0000 \\
\hline
\end{tabular}
$\triangle S A L E S_{i t-1}$ is the change in sales for year $t-1$; according to the equation of Roychowdhury's model, we multiply the two sides of the equation by the assets, and perform the regression to obtain the coefficient, as well as residuals. We take the absolute value of the residual division asset as the measure of real earnings management.

***significant at the $1 \%$ level, **significant at the $5 \%$ level, *significant at the $10 \%$ level

\subsection{Heterogeneity of Institutional Investors}

With reference to the practice of Elyasiani and Jia (2008), Niu Jianbo (2013) and Li Zhengguang (2015), this paper uses industry and time to measure the heterogeneity of institutional investors. 
The formula is as follows:

$$
\left\{\begin{array}{c}
S D_{i t}=I N V H_{i t} / S T D\left(I N V H_{i t-3}, I N V H_{i t-2}, I N V H_{i t-1}\right) \\
S T A B L E_{i t}=\left\{\begin{array}{c}
1, S D_{i t} \geq \operatorname{MEDIAN_{ij}}\left(S D_{i t}\right) \\
0, \text { others }
\end{array}\right.
\end{array}\right.
$$

Among these values, $I N V H_{i t}$ represents the institutional investor shareholding ratio of enterprise $i$ in year $t$; STD $\left(I N V H_{i t-3}, I N V H_{i t-2}, I N V H_{i t-1}\right)$ indicates the standard deviation of institutional investor ownership in the former three-year financial reports; $S D_{i t}$ represents the heterogeneity of institutional investors (measured by the time dimension); $\operatorname{MEDIAN}_{i j}\left(S D_{i t}\right)$ represents the middle position of industry $\mathrm{j}$ of $S D_{i t}$ in year $t$; and $S T A B L E_{i t}$ is a dummy variable, indicating that the heterogeneity of institutional investors is measured from the industry dimension. When $S D_{i t} \geq \operatorname{MEDIAN} N_{i j}\left(S D_{i t}\right), S T A B L E_{i t}$ is 1 , indicating that institutional investors of enterprise $i$ in year $t$ are a stable type of long-term shareholding of the enterprise; otherwise, it is 0 , which means institutional investors of enterprise $i$ in year $t$ is a short-term transient type.

\subsection{Control Variables}

Referring to the previous literature, this paper uses relevant explanatory variables as controls, listed as follows. The first is the size of the company (SIZE): the larger that the scale of the company is, the more that external investors focus on the value of the enterprise, which can affect the financing cost of the enterprise. Among them, the size of the enterprise is generally measured by the natural logarithm of the total assets of the accounting year. The second is leverage (LEV): judging the corporate debt situation and the index of capital structure, different leverage will cause the financial analysis indicators to become unbalanced, which will affect the return rate required by the investment enterprises of the external investors, that is, the cost of the equity 
capital of the company. The measure is the total assets of the enterprise divided the total liabilities. The third is the total asset return (ROA): the net profit rate of the company is equal to the net profit after tax, divided by the total assets of the company. The empirical evidence shows that the total asset yield of the company is positively related to earnings management (Dechow, 1998). At the same time, the net profit margin of the company is considered by the overwhelming majority of institutional investors to assess the financial indicators of a company, which affects the rate of return required by the investor and reflects the cost of equity financing of the company. The market price ratio (MB) is the fair value of enterprises in the stock market divided by the enterprise's book value as an alternative to Tobin's Q. Empirical analysis shows that information asymmetry often occurs between the owners and corporate governance managers of high-technology enterprises (Ping-Sheng Koh, 2007), and asymmetrical information is caused by management to whitewash financial statements by manipulating the real earnings management of revenues and expenses. In addition, as a fast-growing company is considered a "white horse stock" with high growth in the capital market, it may cause an overvaluation of the stock price. To overestimate the value of the white horse stock, there may be a higher investment risk, so investors might ask for higher returns, which will affect the cost of equity capital.

\subsection{Model}

(1) The influence of earnings management on the cost of equity

$$
\begin{gathered}
\mathrm{CoE}_{i t}=a_{0}+a_{1} R E M_{i t}+a_{2} \text { SIZE }_{i t}+a_{3} L E V_{i t}+a_{4} R O A_{i t}+a_{5} M B_{i t} \\
+a_{6} \text { Beta }_{i t}+\sum \text { industry }+\sum \text { year }++\varepsilon_{i t}
\end{gathered}
$$


where $\mathrm{CoE}_{i t}$ represents the cost of equity. $R E M_{i t}$ represents the earnings management measure of company $i$ in year $t$, using the absolute value of $\varepsilon_{i t}$ to measure the abnormal level based on Roychowdhury (2006).

(2) The influence of institutional investors and earnings management on the cost of equity capital.

$$
\begin{aligned}
\mathrm{CoE}_{i t}=b_{0} & +b_{1} R E M_{i t}+b_{2} I N S T_{i t}+b_{3} S I Z E_{i t}+b_{4} L E V_{i t}+b_{5} R O A_{i t} \\
& +b_{6} M B_{i t}+b_{7} \text { Beta }_{i t}+\sum \text { industry }+\sum \text { year }+\varepsilon_{i t}
\end{aligned}
$$

where $\mathrm{CoE}_{i t}$ represents the cost of equity. $R E M_{i t}$ represents the earnings management measure of company $i$ in year $t$, using the absolute value of $\varepsilon_{\mathrm{it}}$ to measure the abnormal level based on Roychowdhury (2006). INST $T_{i t}$, a dummy, represents the heterogeneity of institutional investors.

Table 2 Variables and their definition

\begin{tabular}{ll}
\hline \multicolumn{1}{c}{ Variables } & \multicolumn{1}{c}{ Definition } \\
\hline CoE & Cost of capital, the dependent variable, estimated by the asset pricing \\
& model (CAPM) \\
REM & Real earnings management, estimated by the absolute value of $\varepsilon_{i t}$ to \\
& measure the abnormal level based on Roychowdhury (2006) model \\
INST & A dummy variable representing the heterogeneity of institutional \\
& investors. 1 indicates that institutional investors of enterprise $i$ in $t$ year \\
& is a stable type of long-term shareholding of the enterprise; otherwise, it \\
& is 0 \\
SIZE & Measured by the natural logarithm of total assets \\
LEV & Total debt divided by total assets \\
ROA & The net profit rate of the company is equal to the net profit after tax/the \\
& total assets \\
MB & Fair value of enterprise in the stock market divided by enterprise book \\
& value \\
BETA & Systematic risks
\end{tabular}

\section{Empirical Analysis}




\subsection{Descriptive Statistics}

Table 3 shows the industry distribution of the full sample, the sum of stable institutional investors and transient institutional investors and their proportion. According to the classification standard of the China Securities Regulatory Commission, the samples are categorized in table 3. Industry A stands for agriculture, forestry, animal husbandry and fishery; B for mining; C for manufacturing; D for electricity, gas and water production and supply; E for construction; F for wholesale and retail trade; $G$ for transportation, warehousing and postal services; I for information transmission, software and information technology services; J for finance; $\mathrm{K}$ for real estate; $\mathrm{L}$ for leasing and business services; $\mathrm{M}$ for scientific research and technology services; $\mathrm{N}$ for water conservancy, environment and public facilities management; $\mathrm{R}$ for culture, sports and entertainment; and $\mathrm{S}$ for integration. We easily find that high-tech companies are concentrated in manufacturing and information transmission, accounting for $81.83 \%$ and $9.83 \%$ of high-tech companies, respectively. In addition, the table shows that institutional investors are less than half of all institutional investors, indicating that more than half of the institutional investors tend to transact in the short term for capital gains in China.

Table 3

\section{Descriptive statistics of the heterogeneity of institutional investors: all samples}

\begin{tabular}{lrrrrrr}
\hline & \multicolumn{2}{c}{ All samples } & \multicolumn{2}{c}{ Stable(long-term) investors } & Unstable(transient)investors \\
\hline A & 41 & $0.55 \%$ & 25 & $0.78 \%$ & 16 & $0.38 \%$ \\
B & 60 & $0.81 \%$ & 25 & $0.78 \%$ & 35 & $0.83 \%$ \\
C & 6099 & $81.83 \%$ & 2677 & $83.16 \%$ & 3422 & $80.82 \%$ \\
D & 37 & $0.50 \%$ & 5 & $0.16 \%$ & 32 & $0.76 \%$ \\
E & 109 & $1.46 \%$ & 44 & $1.37 \%$ & 65 & $1.54 \%$ \\
F & 67 & $0.90 \%$ & 28 & $0.87 \%$ & 39 & $0.92 \%$ \\
G & 38 & $0.51 \%$ & 4 & $0.12 \%$ & 34 & $0.80 \%$ \\
I & 733 & $9.83 \%$ & 307 & $9.54 \%$ & 426 & $10.06 \%$ \\
J & 25 & $0.34 \%$ & 8 & $0.25 \%$ & 17 & $0.40 \%$ \\
\hline
\end{tabular}




\begin{tabular}{lrrrrrr}
\hline $\mathrm{K}$ & 18 & $0.24 \%$ & 5 & $0.16 \%$ & 13 & $0.31 \%$ \\
$\mathrm{~L}$ & 63 & $0.85 \%$ & 28 & $0.87 \%$ & 35 & $0.83 \%$ \\
$\mathrm{M}$ & 66 & $0.89 \%$ & 24 & $0.75 \%$ & 42 & $0.99 \%$ \\
$\mathrm{~N}$ & 67 & $0.90 \%$ & 26 & $0.81 \%$ & 41 & $0.97 \%$ \\
$\mathrm{R}$ & 17 & $0.23 \%$ & 4 & $0.12 \%$ & 13 & $0.31 \%$ \\
$\mathrm{~S}$ & 13 & $0.17 \%$ & 9 & $0.28 \%$ & 4 & $0.09 \%$ \\
\hline Total & 7453 & $100.00 \%$ & 3219 & $100.00 \%$ & 4234 & $100.00 \%$ \\
\hline
\end{tabular}

Note: Table 3 shows the industry distribution of the full sample, the sum of stable institutional investors and transient institutional investors identified by equation 3 and their proportion, respectively. According to the classification standard of the China Securities Regulatory Commission, the samples are categorized in the table. Industry A stands for agriculture, forestry, animal husbandry and fishery; B for mining; C for manufacturing; D for electricity, gas and water production and supply; E for construction; $\mathrm{F}$ for wholesale and retail trade; $\mathrm{G}$ for transportation, warehousing and postal services; I for information transmission, software and information technology services; J for finance; $\mathrm{K}$ for real estate; $\mathrm{L}$ for leasing and business services; $\mathrm{M}$ for scientific research and technology services; $\mathrm{N}$ for water conservancy, environment and public facilities management; $\mathrm{R}$ for culture, sports and entertainment; and $\mathrm{S}$ for integration.

Table 4 panel A presents the descriptive statistical results for all samples. The statistical results show that among the 7453 selected sample observations, the average cost of equity financing measured by CAPM is $1.25 \%$, which is lower than the yield of ten-year Treasury bonds. On the one hand, the market annual rate of return considering the monthly average rate of cash dividend reinvestment might be influenced by fluctuations in the Chinese securities market. On the other hand, the total fair value of most of the technology stocks is small, resulting in investors being keen to speculate and make blind investments, thus reducing the companies' cost of financing. Real earnings management, which is measured by Roychowdhury's (2006) absolute value model, is used as the measure of substantial earnings management in high-tech enterprises. The p50 level reaches $0.06 \%$, and the average level reaches $9.07 \%$. According to the analysis of the characteristics of stable institutional investors and transactional institutional investors, it is found that the proportion of stable investors in high-tech enterprises is approximately $43 \%$, showing that the current situation in China remains dominated by short-term transactions to obtain capital dividends; the control variables such as size (SIZE), leverage (LEV), net asset profit (ROA) and book-to-market ratio (MB) are in line with expectations except for a few 
enterprises in several years.

Table 4 panel B presents the descriptive statistical results for industry C, manufacturing, which will be used to perform the robustness test.

Table 4

Descriptive statistics of all samples (panel A) and industry C (panel B)

\begin{tabular}{lllllrrrr}
\hline Panel A & Obs & Mean & Max & Min & p25 & p50 & p75 & \multicolumn{1}{l}{ SD } \\
CoE $\%)$ & 7453 & 1.252232 & 752.65 & -314.247 & -10.5558 & 2.95613 & 9.54521 & 29.51667 \\
INST & 7453 & 0.431907 & 1 & 0 & 0 & 0 & 1 & 0.495375 \\
REM & 7453 & 0.090689 & 11.2176 & $3.50 \mathrm{E}-06$ & 0.027161 & 0.062388 & 0.115024 & 0.18968 \\
SIZE & 7453 & 21.72304 & 27.4868 & 19.2372 & 20.9861 & 21.6215 & 22.3175 & 1.01281 \\
LEV & 7453 & 0.371288 & 1.53259 & 0.007521 & 0.217154 & 0.361384 & 0.506495 & 0.193686 \\
ROA & 7453 & 0.606523 & 0.599886 & -1.31931 & 0.029804 & 0.055509 & 0.089161 & 0.067134 \\
MB & 7453 & 4.219811 & 405.158 & -91.7617 & 2.20312 & 3.24884 & 4.89196 & 8.184224 \\
BETA & 7453 & 1.097339 & 32.2589 & -23.6435 & 0.6169 & 1.1752 & 1.5881 & 1.194807 \\
\hline Panel B & Obs & Mean & Max & Min & p25 & p50 & p75 & SD \\
\hline CoE(\%) & 6099 & 1.344376 & 752.65 & -314.247 & -10.5035 & 2.95705 & 9.58324 & 29.87136 \\
INST & 6099 & 0.438924 & 1 & 0 & 0 & 0 & 1 & 0.496296 \\
REM & 6099 & 0.081341 & 1.62382 & $1.10 \mathrm{E}-05$ & 0.026105 & 0.059803 & 0.109577 & 0.086868 \\
SIZE & 6099 & 21.75176 & 25.7436 & 19.2372 & 21.0276 & 21.6498 & 22.3391 & 0.99759 \\
LEV & 6099 & 0.373292 & 1.53259 & 0.007521 & 0.220183 & 0.364706 & 0.507898 & 0.191737 \\
ROA & 6099 & 0.061006 & 0.586342 & -0.7809 & 0.02939 & 0.055363 & 0.089929 & 0.064762 \\
MB & 6099 & 4.009353 & 347.078 & -49.9771 & 2.1449 & 3.12656 & 4.72064 & 7.006032 \\
BETA & 6099 & 1.095009 & 32.2589 & -23.6435 & 0.6207 & 1.1736 & 1.5773 & 1.220353 \\
\hline
\end{tabular}

Note: Panel A in this table presents descriptive statistics for the major variables used in the full model sample. Panel B in this table presents descriptive statistics for manufactory for the major variables used in the model above. All the variables are defined in table 2.

\subsection{Empirical Test}

In this paper, by constructing unbalanced panel data, the following regression coefficient table is obtained in the following, while the Hausman test shows that they are consistent with the fixed effect. Table 5 shows that real earnings management is 
significantly negatively correlated with the cost of equity capital. When REM changes one unit, it will affect the cost of equity by approximately $-5.5 \%$. Thus, when the earnings behavior conducted by management reaches $1 \%$, the financing cost of equity could be reduced by $0.055 \%$, which indicates that the earnings management by key management in listed high-tech enterprises in China cannot be identified easily, which reduces the cost of equity capital and strongly supports H1. The results are also consistent with previous research showing that REM is more difficult to detect than DA and that REM activities are normally less subject to external monitoring or scrutiny. REM is also more difficult to detect by internal monitors, such as the board or audit committee. As a result, REM may not be curtailed by a good governance mechanism (Jaggi et al., 2009), thereby making external investors' evaluation of firm performance more difficult. As a result, managers can misappropriate more cash if their firms' true performance is masked by REM. This managerial opportunism causes outside investors to assess the expected level of future cash flows to be lower for REM-intensive firms, decreasing the investors' expectation of return and reduces the cost of equity in China. In terms of control variables, BETA is significantly positively correlated with the cost of equity financing, indicating that the higher the systemic risk of the company, the higher the cost of equity. The size of the company is significantly positively correlated with the cost of equity financing, which shows that investors in China are keen to invest the listed high-tech companies with the small fair value, resulting in larger enterprises' shares being seriously undervalued. This is because of that unlike the markets in developed countries, individual investors comprise the majority in the Chinese stock market and most of them are speculative investors who lack of investment knowledge (Jiang and Kim, 2015) and usually overestimate or underestimate and expect mismatched returns (Ma, Song and Zhang, 2019). The asset-liability ratio LEV is significantly negatively correlated with the cost 
of equity, showing that the high debt ratio has a negative impact on shareholders' returns, which also reflects that the debt behavior of listed companies in China remains in the passive debt stage; that is, listed companies do not take the initiative in debt financing to improve shareholders' returns. The company's book-to-book ratio (MB) is significantly positively correlated with the cost of equity, which indicates that as $\mathrm{MB}$ increases, the operational risk of these enterprises increases, resulting in a higher cost of equity. These findings are consistent with the research conducted by Ye and $\mathrm{Lu}$ (2004). The ROE of profitability is significantly positively correlated with the cost of equity financing, indicating that as the profitability of the company increases, the higher the expected return of shareholders and the higher the cost of equity. These findings are consistent with the research conducted by Jiang and $\mathrm{Lu}$ (2006).

Table 5

Regressions of the relationship between real earnings management and cost of

\begin{tabular}{lll}
\multicolumn{1}{c}{ equity } \\
\hline Variables & Coef. & $\mathrm{p}>|\mathrm{t}|$ \\
\hline REM & $-5.558223^{* * *}$ & 0.002 \\
SIZE & $3.056324 * * *$ & 0.000 \\
LEV & $-5.972715^{* * *}$ & 0.005 \\
ROA & $-15.6113^{* * *}$ & 0.003 \\
MB & $0.1621587 * * *$ & 0.000 \\
BETA & $4.477408^{* * *}$ & 0.000 \\
Intercept & $-67.0694 * * *$ & 0.000 \\
Adjusted $\mathrm{R}^{2}$ & 0.2483 & \\
F & $62.93 * * *$ & 0.0000
\end{tabular}

Note: Table 5 presents the regression results of model 4 with the coefficient and significance. All the variables are defined in table 2.

$* * *$ significant at the $1 \%$ level, **significant at the $5 \%$ level, *significant at the $10 \%$ level

From column 1 of table 6 , we can see that the heterogeneity of institutional investors is significantly negatively correlated with the cost of equity capital, and it is significant at $1 \%$. This finding shows that, compared with transactional institutional 
investors, stable institutional investors can effectively reduce the cost of equity capital. $\mathrm{H} 2$ is verified.

To verify the reliability of the conclusion, we divide the sample into two groups according to the heterogeneity of institutional investors: stable institutional investors and transient institutional investors, then we regress model 4 with the two groups of samples in columns 2 and 3 of table 6 . The coefficient of REM is still significantly negatively related to $\mathrm{CoE}$, and $\mathrm{H} 1$ is verified again.

At the same time, we find that when REM changes one unit, the cost of equity will reduce approximately $2.38 \%$ under the constraint of stable institutional investors and $10.87 \%$ with transient institutional investors, both significant at the $1 \%$ level. This means that the earnings management under the supervision of the stable institutional investors could possibly be identified and could diminish the earnings management's impact on the cost of equity, which confirms the role of stable institutional investors from another perspective. $\mathrm{H} 2$ is verified again.

The relationship between the relevant control variables and the cost of equity is almost consistent with the conclusion obtained in table 5 .

Table 6

Regressions of the relationship between real earnings management and cost of equity

\begin{tabular}{l|l|l|l|l|l|l}
\hline \multicolumn{4}{|l|}{ All samples } & \multicolumn{2}{l|}{$(1)$ INST $=1$} & \multicolumn{2}{l}{$(2)$ INST $=0$} \\
\hline Variables & Coef. & $\mathrm{p}>|\mathrm{t}|$ & Coef. & $\mathrm{p}>|\mathrm{t}|$ & Coef. & $\mathrm{p}>|\mathrm{t}|$ \\
\hline REM & $-1.902177 * *$ & 0.013 & $-2.381128 * * *$ & 0.007 & $-10.8751 * * *$ & 0.000 \\
INST & $-10.51712 * * *$ & 0.000 & & & & \\
SIZE & $3.076918 * * *$ & 0.000 & $2.954472 * * *$ & 0.000 & $2.947113 * * *$ & 0.000 \\
LEV & $-5.580217 * * *$ & 0.009 & -3.240884 & 0.294 & $-7.371327 * *$ & 0.012 \\
ROA & $-14.71788 * * *$ & 0.005 & $-20.82576 *$ & 0.080 & -3.580084 & 0.615 \\
MB & $0.1617495 * * *$ & 0.000 & 0.0659553 & 0.44 & $0.2396292 * * *$ & 0.000 \\
BETA & $4.485941 * * *$ & 0.000 & $2.570523 * * *$ & 0.000 & $7.405053 * * *$ & 0.000
\end{tabular}




\begin{tabular}{l|l|l|l|l|l|l} 
Intercept & $-66.74506 * * *$ & 0.000 & $-63.43378 * * *$ & 0.000 & $-67.40632 * * *$ & 0.000 \\
Adjusted R & 0.2493 & & 0.2323 & & 0.2781 & \\
F & $48.21 * * *$ & 0.0000 & $17.89 * * *$ & 0.000 & $59.69 * * *$ & 0.000 \\
\hline
\end{tabular}

Note: Table 6 column 1 (all samples) presents the regression results of model 5 with the coefficient and significance. Then, the samples are divided into two groups according to the heterogeneity of institutional investors (model 3): stable institutional investors and transient institutional investors and then we regress model 4 with the two groups of samples shown in columns 2 and 3 of table 6 . All the variables are defined in table 2 .

$* * *$ significant at the $1 \%$ level, **significant at the $5 \%$ level, *significant at the $10 \%$ level

\subsection{Robustness Test}

4.3.1 Robustness test by 5 th and 95 th percentiles samples

To avoid possible bias from extreme values, the study also adopts samples within the 5th and 95th percentiles of all sample data as measures for the robustness test (Huang \& Liu, 2011). The results are shown in table 7. Compared with tables 5 and 6, there is no essential change in the research results. Hypotheses 1, and 2 are verified again.

\section{Table 7}

\section{Regressions of the relationship between real earnings management and cost of} equity (from $5^{\text {th }}$ to $95^{\text {th }}$ percentile)

\begin{tabular}{|c|c|c|c|c|c|c|c|c|}
\hline \multirow[b]{2}{*}{ Variables } & \multicolumn{2}{|l|}{ All samples } & \multicolumn{2}{|l|}{ All samples } & \multicolumn{2}{|l|}{ (1) INST $=1$} & \multicolumn{2}{|l|}{ (2) $\mathrm{INST}=0$} \\
\hline & Coef. & $\mathrm{p}>|\mathrm{t}|$ & Coef. & $\mathrm{p}>|\mathrm{t}|$ & Coef. & $\mathrm{p}>|\mathrm{t}|$ & Coef. & $p>|t|$ \\
\hline REM & $-4.029841 * * *$ & 0.000 & $-.7997932 *$ & 0.078 & $-2.362696 * * *$ & 0.007 & $-6.995338 * * *$ & 0.000 \\
\hline INST & & & $-7.103781 * * *$ & 0.000 & & & & \\
\hline SIZE & $1.799127 * * *$ & 0.000 & $1.783373 * * *$ & 0.000 & $2.256799 * * *$ & 0.000 & $2.013415^{* * *}$ & 0.000 \\
\hline LEV & -0.8596142 & 0.507 & -0.6890662 & 0.597 & -1.571181 & 0.409 & -2.263896 & 0.209 \\
\hline ROA & $-8.131068 * * *$ & 0.011 & $-7.782916^{* *}$ & 0.015 & $-22.20025^{* * *}$ & 0.000 & -2.870626 & 0.511 \\
\hline MB & $0.1067702 * * *$ & 0.000 & $0.1063747 * * *$ & 0.000 & $0.5958941^{* * *}$ & 0.000 & $0.0671186^{* *}$ & 0.017 \\
\hline BETA & $3.949983^{* * *}$ & 0.000 & $3.952756 * * *$ & 0.000 & $3.040216^{* * * *}$ & 0.000 & $4.664038 * * *$ & 0.000 \\
\hline Intercept & $-40.84184 * * *$ & 0.000 & $-40.14465^{* * *}$ & 0.000 & $-51.02141 * * *$ & 0.000 & $-45.42152 * * *$ & 0.000 \\
\hline Adjusted $\mathrm{R}^{2}$ & 0.2703 & & 0.2711 & & 0.2649 & & 0.2889 & \\
\hline $\mathrm{F}$ & $84.39 * * *$ & 0.000 & $64.11 * * *$ & 0.0000 & $33.85 * * *$ & 0.000 & $61.23 * * *$ & 0.000 \\
\hline
\end{tabular}

Note: Table 7 column 1 (all samples from 5th to 95th percentiles) presents the 
regression results of model 4 with the coefficient and significance. Table 7 column 2 (all samples from the 5th to 95th percentiles) presents the regression results of model 5 with the coefficient and significance. Then, the samples are divided into two groups according to the heterogeneity of institutional investors (model 3): stable institutional investors and transient institutional investors and then we regress model 4 again with the two groups of samples shown in columns 3 and 4 of table 7 . All the variables are defined in table 2 .

$* * *$ significant at the $1 \%$ level, **significant at the $5 \%$ level, *significant at the $10 \%$ level

\subsubsection{Robustness test by industry control}

Because most of the high-tech enterprises in this paper are distributed in the manufacturing industry classified by the SEC, we control the industry in manufacturing and regress the data from panel $\mathrm{B}$ in the table as measures for the robustness test. The results are shown in table 8 . Compared with table 5 and table 6 , there is no essential change in the research results. Hypotheses 1 and 2 are verified again.

\section{Table 8}

Regressions of the relationship between real earnings management and cost of equity (control the industry in manufacturing)

\begin{tabular}{|c|c|c|c|c|c|c|c|c|}
\hline \multirow[b]{2}{*}{ Variables } & \multicolumn{2}{|l|}{$\begin{array}{l}\text { All samples in } \\
\text { manufacturing }\end{array}$} & \multicolumn{2}{|c|}{ All samples in manufacturing } & \multicolumn{2}{|l|}{ (1) INST =1 } & \multicolumn{2}{|l|}{ (2) $\mathrm{INST}=0$} \\
\hline & Coef. & $\mathrm{p}>|\mathrm{t}|$ & Coef. & $\mathrm{p}>|\mathrm{t}|$ & Coef. & $\mathrm{p}>|\mathrm{t}|$ & Coef. & $\mathrm{p}>|\mathrm{t}|$ \\
\hline REM & $-18.90952 * * *$ & 0.000 & $-1.881434^{*}$ & 0.072 & -9.223338 & 0.176 & $-24.41528 * * *$ & 0.000 \\
\hline INST & & & $-23.7729 * * *$ & 0.000 & & & & \\
\hline SIZE & $2.71483^{* * *}$ & 0.00 & $2.76758 * * *$ & 0.000 & $2.524876 * * *$ & 0.000 & $2.605142 * * *$ & 0.000 \\
\hline LEV & -7.326305 & 0.507 & $-7.047061 * * *$ & 0.004 & $-3.849317 * * *$ & 0.274 & $-9.069286 * * *$ & 0.007 \\
\hline ROA & $-18.16013 * *$ & 0.011 & $-17.8785^{* * *}$ & 0.004 & $-17.73794 * * *$ & 0.050 & -12.72815 & 0.128 \\
\hline $\mathrm{MB}$ & $0.1251913 * * *$ & 0.000 & $0.1229783 * *$ & 0.024 & $-.2585259 * * *$ & 0.006 & $0.29378 * *$ & 0.017 \\
\hline BETA & $4.3035 * * *$ & 0.000 & $3.952756 * * *$ & 0.000 & $2.48832 * * *$ & 0.000 & $7.356467 * * *$ & 0.000 \\
\hline Intercept & $-57.54143 * * *$ & 0.000 & $-57.99608 * * *$ & 0.000 & $-52.45908 * * *$ & 0.000 & $-57.98091 * * *$ & 0.000 \\
\hline Adjusted R² & 0.2460 & & 0.2465 & & 0.2318 & & 0.2784 & \\
\hline $\mathrm{F}$ & $48.91 * * *$ & 0.000 & $37.11 * * *$ & 0.0000 & $14.63 * * *$ & 0.000 & $48.43 * * *$ & 0.000 \\
\hline
\end{tabular}

Note: Table 8 column 1 (all samples in manufacturing) presents the regression results 
of model 4 with the coefficients and significance. Table 8 column 2 (all samples in manufacturing) presents the regression results of model 5 with the coefficients and significance. Then, the samples are divided into two groups according to the heterogeneity of institutional investors (model 3): stable institutional investors and transient institutional investors and then model 4 is regressed again with the two groups of samples shown in columns 3 and 4 of table 8 . All the variables are defined in table 2.

***significant at the $1 \%$ level, **significant at the 5\% level, *significant at the $10 \%$ level

\section{Conclusions}

This paper studies the relationship among institutional investors, real earnings management and the cost of equity capital of listed high-tech companies in China. Real earnings management has direct consequences on current and future cash flows, which is more difficult for average investors to understand, and this behavior might misguide the investors on the required rate of return on investment projects. In addition, the recognition criteria of "Measures for the Identification and Management of High-tech Enterprises" (No. 32 Document published by Chinese National Science and Technology Focus [2016]) could help listed companies obtain income tax relief. This provides great motivation for managers to implement earnings management to meet the benchmark due to the special Chinese capital background. Therefore, we are motivated to test the relationship because the cost of equity is a key factor reflecting the expected return of the outside investors, even determining all social resource allocation decisions. Through the empirical analysis, we generate the following conclusions and put forward suggestions accordingly.

First, the earnings management of the listed high-tech companies is negatively correlated with the cost of equity capital. This finding is contrary to Kim and Sohn's (2013) conclusion, indicating that, in China, real earnings management cannot be effectively identified by external investors, and the company could easily obtain 
financing from the capital market and reduce its cost of equity due to its masked excellent performance by manipulating the real earnings management. We recommend improving the quality of management and enhancing the sense of professional ethics of senior managers, which will greatly reduce real earnings management based on income and improve enterprises' disclosure mechanism. Instead of managing earnings, managers of listed companies can actively disclose enterprise information to the outside capital market to build up the image of the company and to build trust with investors, which would also reduce the financing costs of equity.

Second, compared with transactional institutional investors, stable institutional investors who intend to hold stock for long terms can effectively reduce the cost of equity capital. Real earnings management under the supervision of stable institutional investors could be more strongly identified, and the stable institutional investors could diminish the impact of earnings management on the cost of equity. Therefore, we strongly suggest that institutional investors play an active role in corporate governance. In the context of emerging markets, such as China, institutional investors can still influence managers' opportunistic behavior s and can have a positive impact on corporate value. Especially in the background of Chinese new economic policy, the introduction of long-term stable institutional investors is needed to promote the development of high-tech enterprises, which could improve the company's external governance mechanism.

There are, however, two shortcomings in this paper. The heterogeneity of institutional investors' shareholding is based on the static indicators disclosed in the annual report, but in fact, institutional investors' shareholding ratio could fluctuate within one year. Future research projects could focus on the impact of institutional investors' shareholding changes on earnings management behavior . In addition, when 
using the CAPM model, the annual return rate of the market, which adopts the monthly average return rate of cash dividend reinvestment, fluctuates greatly in the Chinese stock market. Many studies have adopted the model of the cost of equity from the ex post model to the ex ante model, which inspires us to further study the impact of institutional investors and earnings management on the implied cost of equity.

\section{References}

Almazan, A., Hartzell J.C. and Starks, L.T. 2005. Active institutional shareholders and costs of monitoring: evidence from executive compensation. Financial Management. 34(4), pp.5-34.

Bartov, E., Gul, F.A., and Tsui, J.S.L. 2000. Discretionary accruals models and audit qualifications. Journal of Accounting and Economics. 30, pp.421-452.

Bushee, B. 1998. The influence of institutional investors on myopic R\&D investment behavior. The Accounting Review. 73, pp.305-333.

Bushee, B. 2001. Do institutional investors prefer near-term earnings over long-run value? Contemporary Accounting Research. 18, pp.207-246.

Caton, G.L., Chiyachantana, C.N., Chua, C.T., and Goh, J. 2011. Earnings management surrounding seasoned bond offerings: Do managers mislead ratings agencies and the bond market? Journal of Financial and quantitative analysis. 46(3), pp.687-708.

Cheng, S.Q. 2006. Empirical Study on the Relationship between Institutional Investor Holdings and Listed Companies' Accounting Earnings Information. Management World. 9, pp.129-136

Chiu, P.C., Teoh, S.H. and Tian, F. 2013. Board interlocks and earnings management contagion. The Accounting Review. 88(3), pp.915-944.

Chung, K.H. and Zhang, H. 2011. Corporate governance and institutional ownership. Journal of Financial and Quantitative Analysis. 46(1), pp.247-273.

Chung, R., Firth, M. and Kim, J.B. 2002. Institutional Monitoring and Opportunistic Earnings Management. Journal of Corporate Finance. 8(1), pp.29-48

Datta, S., Iskandar-Datta, M. and Singh, V. 2013. Product market power, industry structure, and corporate earnings management. Journal of Banking and Finance. 37(8), pp.3273-3285.

Daniel Olausson. and Christian Berggren. 2010. Managing uncertain complex 
product development in high-tech firms: in search of controlled flexibility. $R \& D$ Management. 40(4).pp.383-399

Dechow, P.M., Kothari, S.P. and Watts, R.L. 1998. The relation between earnings and cash flows. Journal of Accounting and Economics. 25(2), pp.133-168.

Dechow, P., Sloan, R.. and Sweeny, A. 1995. Detecting earnings management. The Accounting Review. 70, pp.193-225.

Degeorge, F., Ding.Y., Jean, T. and Stolowy, H. 2013. Analyst coverage, earnings management and financial development: An international study. Journal of Accounting and Public Policy. 32, pp. 1-25.

Devesh Verma, Anant Mishra and Kingshuk K. Sinha. 2010. The development and application of a process model for $R \& D$ project management in a high tech firm: A field study. Journal of Operations Management. 29(5), pp.462-472

Ding, S., M. J. Kim, and X. Zhang. 2018. Do firms care about investment opportunities? Evidence from China. Journal of Corporate Finance 52, pp.214-37.

Elyasiani, E., Jia. J. and Mao, C. 2010. Institutional Ownership Stability and The Cost of Debt. Journal of Financial Markets. 13(4), pp. 475-500

Essid, W. 2012. Executive stock options and earnings management: is there an option level dependence? Corporate Governance. 12(1), pp.54-70.

Francoeur, C., Amar, W.B. and Rakoto, P. 2012. Ownership structure, earnings management and acquiring firm post-merger market performance Evidence from Canada. International Journal of Managerial Finance. 8(2), pp.100-119.

Fudenburg, D. and Tirole, J. 1995. A theory of income and dividend smoothing based on incumbency rents. Journal of Political Economy. 103, pp.75-93.

Gao, L. and Zhang, J. 2008. Corporate Governance, Institutional Investors and Earnings Management. Accounting Research, 9, pp.64-72

Gaspar, J.M., Massa, M. and Matos, P. 2005. Shareholder Investment Horizons and the Market for Corporate Control. Journal of Financial Economic. 76(1), pp.135-165

Graham, J., Harvey, C. and Rajgopal, S. 2005. The economic implications of corporate financial reporting. Journal of Accounting and Economic. 40, pp.3-73.

Greiner, A.J. 2015.The effect of the fair value option on bank earnings and regulatory capital management: Evidence from realized securities gains and losses Advances in Accounting. Advances in International Accounting. DOI : 10.1016/j.adiac.2015.03.005

Hansen, J.C. 2010. The effect of alternative goals on earnings management studies: An earnings benchmark examination. Journal of Accounting and Public Policy. 29, pp.459-480. 
He, D., Yang, D.C. and Guan, L. 2011. Earnings management and long-run stock underperformance of private placements. Academy of Accounting and Financial Studies Journal. 15(1), pp.31-58.

Healy, P.M. and Wahlen, J.M. 1999. A Review of the earnings management literature and its implications for standard setting. Accounting Horizons. 13(4), pp.365-383.

Hoglund, H. 2012. Detecting earnings management with neural networks. Expert Systems with Applications. 39, pp.9564-9570.

Huang, D.T. and Liu, Z.C. 2011. The relationships among governance and earnings management: An empirical study on non-profit hospitals in Taiwan. African Journal of Business Management. 5(14), pp.5468-5476.

Jaggi, B., Leung, S. and Gul, F. 2009. Family control, board independence and earnings management: evidence based on Hong Kong firms. Journal of Accounting and Public Policy. 28, pp.281-300.

Jiang, F., and K. A. Kim. 2015. Corporate governance in China: A modern perspective. Journal of Corporate Finance 32, pp.190-216.

Jiang, F.X. and Lu, Z.F. 2006. The Relation Between Diversification and Cost of Capital: Evidence from Chinese Stock Market. Accounting Research. 6, pp.48-55

Jiang, F.X. Zhi X.Q. and Zhang M. 2008. Investor Protection and Equity Financing Cost: A Case Study of Chinese Listed Companies. Management World. 2 pp.117-125

Jones, J. 1991. Earnings management during import relief investigations. Journal of Accounting Research. 29, pp.1-31.

Kangarluei, S.J., Motavasse, M. and Abodllahi, T. 2011. The investigation and comparison of free cash flows in the firms listed in Tehran Stock Exchange (TSE) with an emphasis on earnings management. International Journal of Economics and Business Modeling. 2(2), pp.118-123.

Kim, J.B. and Sohn, B.C. 2013. Real Earnings Management and Cost of Capital. Journal of Accounting and Public Policy. 32, pp.518-543.

Li, Z.G., Zhao, X.B and Cao, F. 2014. Institutional investor heterogeneity and firm performance: empirical evidence from Chinese listed companies. Journal of Audit and Economics. 29(5), pp.77-87.

Lin, F.Y. and Wu, S.F. 2014. Comparison of cosmetic earnings management for the developed markets and emerging markets: Some empirical evidence from the United States and Taiwan. Economic Modelling. 36, pp.466-473.

Liu, J.J. and Xu, H.P. 2012. Institutional Investors: Long-term Investors or Short-term Opportunists? Journal of Financial Research. 9, pp.141-154

Liu, C., Yuen, C.Y., Yao, L.J. and Chan, S.H. 2014. Differences in earnings 
management between firms using US GAAP and IAS/IFRS. Review of Accounting and Finance. 13(2), pp.134-155.

Louis, H. 2004. Earnings management and the market performance of acquiring firms. Journal of Financial Economics. 74, pp.121-148.

Ma, X.X., Song, P.C. and Zhang, X. 2019 The Structural Changes of Liquidity Risk, and Liquidity Risk Premium in China Stock Market, Emerging Markets Finance and Trade, DOI: 10.1080/1540496X.2019.1601554

Matsumoto, D.A. 2002. Management's incentives to avoid negative earnings surprises. Accounting Review. 77, pp.483-514.

Mei, J. and Zhang, M.Z. 2016. Do Funds Lead the Institutional Investors to Govern Listed Firms' Earnings Management: Analysis Based on the Endogenous View? Accounting research. 4, pp.55-60

Niu, J.B., Wu, C. and Li, S.N. 2013. Types of Institutional Investors, Equity Characteristics and Voluntary Information Disclosure. Management Review. 25(3), pp.48-59

Patro, B. and Pattanayak, J.K. 2014. Detecting earnings management using accrual-based models:An empirical study with reference to Coal India Ltd. The IUP Journal of Accounting Research and Audit Practices. XIII(2), pp.53-65.

Pauwels, K., Silva-Risso, J., Srinivasan, S. and Hanssens, D., 2004. New products, sales promotions, and firm value: the case of automobile industry. Journal of Marketing. 68, pp.142-156.

Ping-Sheng Koh. 2007. Institutional investor type, earnings management an benchmark beaters. Journal of Accounting and Public Police. 26, pp.267-299

Pourhasan, R.A.A. and Mansour, G. 2014. Comparison of earnings management prediction using neural networks model and modified linear Jones model. Asian Journal of Research in Social Sciences and Humanities. 4(7), pp.456-465.

Rodriguez-Perez, G. and Stefan van Hemmen. 2010. Debt, diversification and earnings management. Journal of Accounting and Public Policy. 29, pp.138-159.

Roychowdhury, S. 2006. Earnings management through real activities manipulation. Journal of Accounting and Economics. 42(3), pp.335-370.

Shi, M.J. and Tong, W.H.. 2009. Does Institutional Investors Increase Corporate Value? Journal of Financial Research. 10, pp.150-161

Stein, J. 1989. Efficient capital markets, inefficient firms: a model of myopic corporate behavior . Quarterly Journal of Economics. 63, pp.655-669.

Sun, J., Lan, G. and Liu, G.P. 2014. Independent audit committee characteristics and real earnings management. Managerial Auditing Journal. 29(2), pp.153-172.

Tsai, C.F. and Chiou, Y.J. 2009. Earnings management prediction: A pilot study of combining neural networks and decision trees. Expert Systems with Applications. 
36, pp.7183-7191.

Wang, Y.P., Wu, L.S. and Bai, Y.X. 2005. Frequency and Magnitude of Earnings Management of Listed Companies in China. Economic Research Journal. 12, pp.102-112

$\mathrm{Wu}$, R.S. 2014. Predicting earnings management: A nonlinear approach. International Review of Economics and Finance. 30, pp.1-25.

Ye, K.T. and Lu, Z.F. 2004. Analysis on the Influencing Factors of Equity Financing Cost of Chinese Listed Companies. Management World. 5, pp.127-131 